\title{
COVID-19-related encephalopathy responsive to high-dose glucocorticoids
}

Deborah Pugin, MD, Maria-Isabel Vargas, MD, Camille Thieffry, MD, Manuel Schibler, MD, PhD, Olivier Grosgurin, MD, Jérôme Pugin, $M D$,* and Patrice H. Lalive, MD*

Neurology ${ }^{\circledR}$ 2020;95:543-546. doi:10.1212/WNL.0000000000010354

One hundred twenty patients with coronavirus disease 2019 (COVID-19) were hospitalized in our intensive care unit, Geneva, Switzerland, between March 9 and April 16, 2020. We report the clinical evolution of 5 consecutive patients intubated because of COVID-19related acute respiratory distress syndrome, presenting with a pathologic recovery of consciousness, which was responsive to high-dose glucocorticoids. These patients all presented with angio-MRI signs of inflammation of CNS arteries, consistent with an endothelialitis rather than a vasculitis. The median time between COVID-19 first symptoms and intubation was 10 days (IQR 10-11 days).

After at least 2 weeks of mechanical ventilation, all 5 patients presented with delayed awakening (Glasgow Coma Scale [GCS] score 4-9). Sedation/agitation Confusion assessment method for the intensive care unit or Richmond agitation sedation scale scores were not measured due to the severity of the impaired consciousness. Other causes of impaired consciousness classically found in such patients were assessed. Metabolic disorders including renal or hepatic insufficiency, dysnatremia, persistence of sedatives effects, or hypoxemia were not present in these patients and could therefore not explain their clinical status (tables S1-S3, available from Dryad, doi.org/10.5061/dryad.dv41ns1vq). An EEG was performed in all patients, ruling out epilepsy showing only nonspecific changes.

A brain MRI with angiographic sequences was performed because of the unexplained signs of encephalopathy. An abnormal contrast enhancement of the vascular wall was noted in all patients, predominantly in the basal skull arteries (V4 portion of the vertebral artery [5/5], basilar artery [2/5], internal carotid in its petrous or supraclinoid portion [3/5], and posterior cerebral arteries $[1 / 5])$. No arterial stenosis or wall thickening was detected, and inflammatory atheromatous plaques were excluded by angio-MR and angio-CT scan or echo-Doppler. Furthermore, no significant abnormalities in the brain parenchyma (except for patient 5 who showed bilateral signs of small watershed ischemia) or diffuse enhancement in leptomeningeal spaces were observed (figure 1).

Following angio-MRI, a CSF sample was obtained for all patients. None displayed white blood cell count abnormalities (except patient 4 with a Waldenström lymphoma) or high protein level. Severe acute respiratory syndrome coronavirus 2 (SARS-CoV-2) real-time reverse transcriptase PCR (rRT-PCR) was negative in all of them. CSF oligoclonal bands (OBs) were present in 5/5 patients, and the pattern was identical in the serum (type $4 \mathrm{OB}$ ) (table S3, available from Dryad, doi.org/10.5061/dryad.dv41ns1vq). One patient (4) had an additional type 5 OBs secondary to Waldenström lymphoma. The intrathecal antibody index for anti-SARS-CoV-2 Immunoglobulins was negative for all patients.

Because angio-MRI showed signs of large intracerebral arterial wall inflammation and SARSCoV-2 rRT-PCR in the CSF was negative, with no other contraindications, a treatment of IV

\author{
Correspondence \\ Dr. Lalive \\ patrice.lalive@hcuge.ch
}

\section{MORE ONLINE}

COVID-19 Resources

For the latest articles, invited commentaries, and blogs from physicians around the world NPub.org/COVID19

\footnotetext{
*These authors contributed equally to this work.

From the Department of APSI (D.P., C.T., J.P.), Intensive Care Unit, Geneva University Hospital; Diagnostic Department (M.-I.V.), Division of Neuroradiology, Geneva University Hospital; Medicine Department (M.S.), Division of Infectiology, Geneva University Hospital; Medicine Department (O.G.), Division of Internal Medicine, Geneva University Hospital; Department of Clinical Neurosciences (P.H.L.), Division of Neurology, Geneva University Hospital; Diagnostic Department (P.H.L.), Division of Laboratory Medicine, Geneva University Hospital; and Department of Pathology and Immunology (P.H.L.), Faculty of Medicine, University of Geneva, Geneva, Switzerland.

Go to Neurology.org/N for full disclosures. Funding information and disclosures deemed relevant by the authors, if any, are provided at the end of the article.
} 


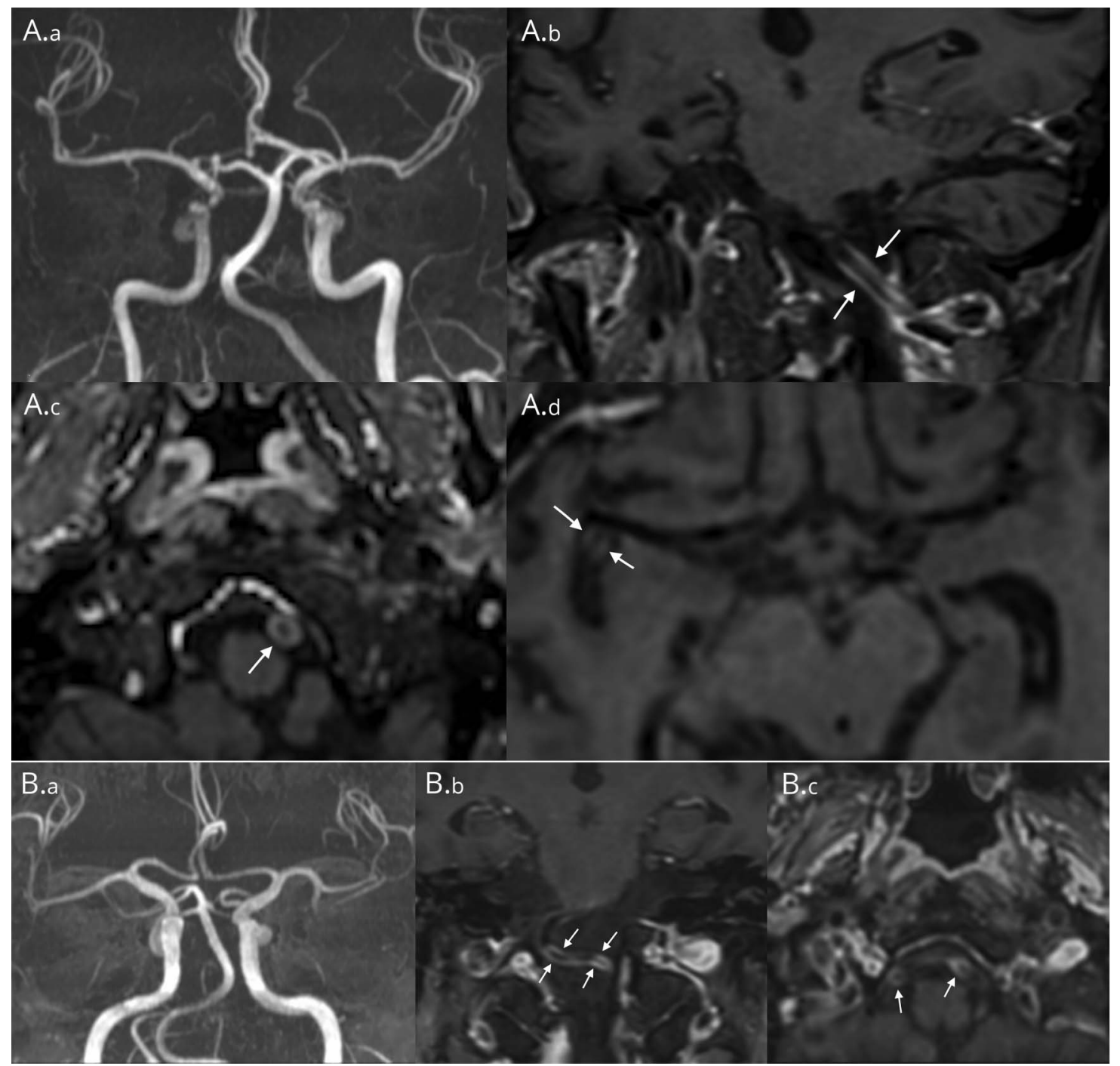

(A) Patient 1: MRI 3D TOF sequence (Ingenia 1.5 T Philips) illustrates an absence of abnormality of caliber of circle of Willis (A.a) associated with an enhancement of the wall of the left vertebral artery (arrows in A.b and A.c) and M2 descendant branch of medial cerebral artery (arrows in A.d) (Turbo spin echo fat saturation ([TSE FAT SAT])). (B) Patient 2: MRI 3D TOF sequence (Ingenia 1.5 T Philips) illustrates a normal circle of Willis (B.a) associated with an enhancement of the wall of vertebral arteries (arrows in B.b and B.c) (3D TSE FAT SAT).

methylprednisolone $500 \mathrm{mg} / \mathrm{d}$ was initiated for 5 days (followed by tapering dose of prednisone in patients 1 and 2). After 48-72 hours, we observed awakening with a dramatic change of the level of consciousness in all patients (figure 2). These patients (GCS score 4-9) woke up with GCS improvement of 5 or more points, allowing extubation in $3 / 5$ patients ( $2 \mathrm{had}$ been tracheostomized due to prolonged weaning of ventilation).

Five to 10 days after the initial dose of steroids, $3 / 5$ patients had fully recovered with a GCS score of 15 . Two patients (1 and 5) were fluctuating with variations of arousal, but when awake, the GCS score was 14. Of note, patient 5 had bilateral small watershed signs of ischemia on MRI. The remainder of the neurologic examination was normal except for generalized weakness of variable importance consistent with a critical illness polyneuropathy and myopathy in 4/5 patients, and 1 patient had diffuse and symmetrical hyperreflexia. To further evaluate the extension of vascular abnormalities, thoracoabdominal angio-CT scan was performed in $3 / 5$ patients. Results were normal in 2 patients. One patient showed a diffuse enhancement of the vascular walls (including renal, hepatic, and iliac vessel walls). None of these 5 patients presented any cutaneous sign of vasculitis.

A retrospective study in Wuhan, China, showed that $36 \%$ of patients (78/214) had neurologic manifestations at onset of COVID-19. Patients with a more severe infection presented with acute cerebrovascular diseases (5.7\%) and impaired consciousness (14.8\%), ${ }^{1}$ but no brain MRI was performed. A French observational study reported 58 ICU patients presenting with significant agitation after withholding sedation $(69 \%)^{2}$ Among them, confusion was present in $26 / 40$ and a dysexecutive syndrome in $15 / 45$. An enhancement in 


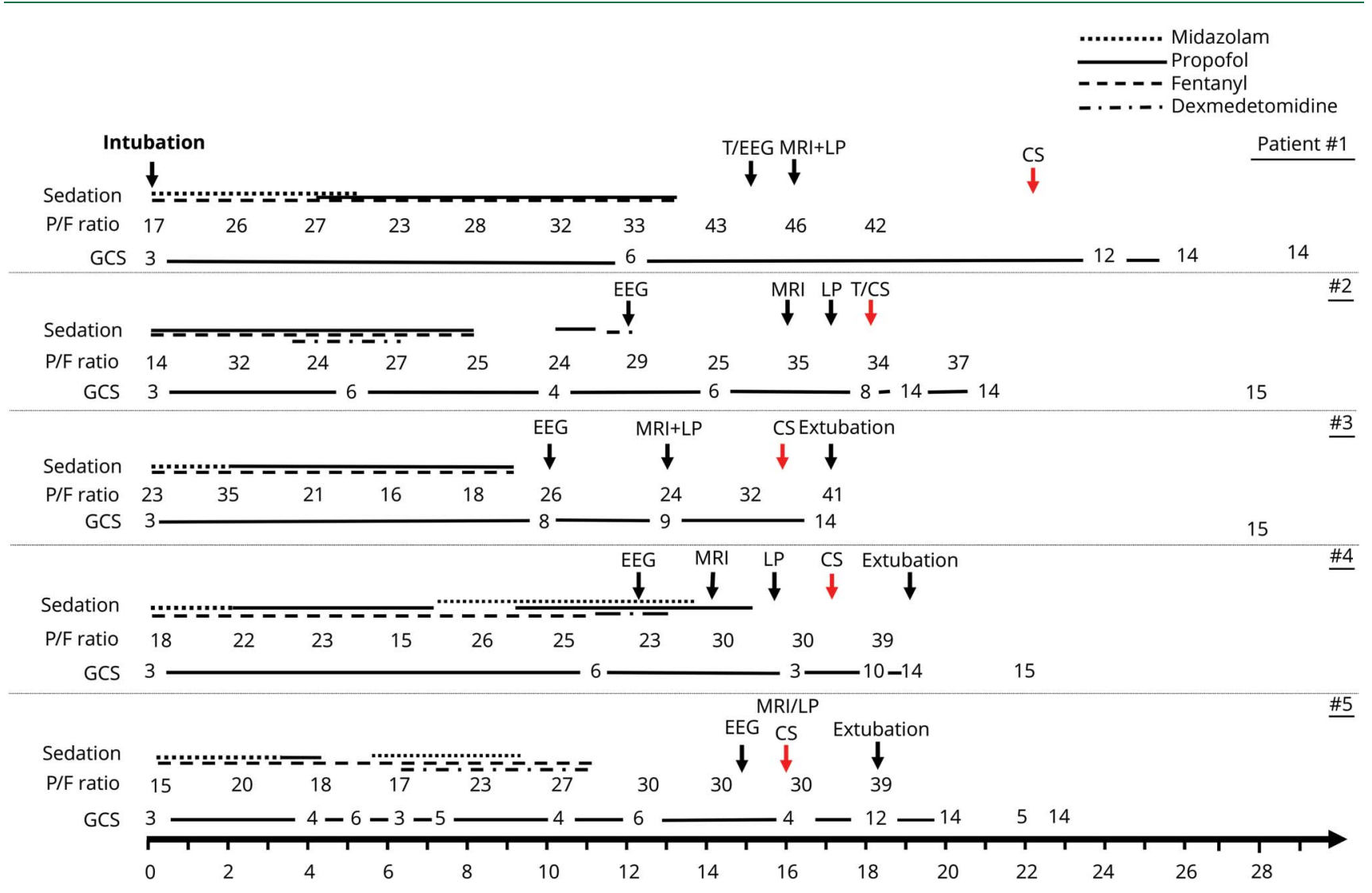

COVID-19 = coronavirus disease 2019; CS = corticosteroids; GCS = Glasgow Coma Scale; LP = lumbar puncture; P/F = PaO2/FiO2 ratio; $T$ = tracheostomy. $\mathrm{X}$ axis: time after intubation.

leptomeningeal spaces was reported in 8/13 patients; such patterns were not observed in our patients. This discrepancy may be explained by different timing of MRI.

In our case series, the abnormalities observed on angio-MRI were limited to an enhancement mainly in the basal skull wall vessels. Of interest, inflammation was predominantly observed in the posterior circulation (basilar and vertebral arteries). A relationship between posterior circulation inflammation and brainstem function may be related to altered consciousness. Of note, full radiologic criteria for a vasculitis - a stenosis of the lumen and thickening of the vessel walls-were missing. Moreover, the brain parenchyma showed no significant abnormalities except in 1 patient. A possible explanation for the radiologic signs of cerebral vascular inflammation includes SARS-CoV-2 endothelial invasion through ACE2 receptors, ${ }^{3}$ consistent with the description of a SARS-CoV-2-induced endothelialitis in autopsy. ${ }^{4}$ An alternative hypothesis includes an encephalopathy secondary to a cytokine storm syndrome, aggravated by increased cerebral vascular permeability. The observation that after the end of steroid therapy, encephalopathy does not recur is more in favor of a postviral inflammatory syndrome than a persistent and uncontrolled viral infection of the endothelial cells.
The observation of COVID-19-related encephalopathy associated with CNS endothelialitis responding to high-dose steroids in ICU patients should be further confirmed by clinical studies.

\section{Study funding}

No targeted funding reported.

\section{Disclosure}

The authors report no disclosures relevant to the manuscript. Go to Neurology.org/N for full disclosures.

\section{Publication history}

Received by Neurology May 8, 2020. Accepted in final form June 30, 2020.

Appendix Authors

\begin{tabular}{lll}
\hline Name & Location & Contribution \\
\hline $\begin{array}{l}\text { Deborah } \\
\text { Pugin, MD }\end{array}$ & $\begin{array}{l}\text { Department of APSI, } \\
\text { Intensive Care Unit, Geneva } \\
\text { University Hospital, } \\
\text { Switzerland }\end{array}$ & $\begin{array}{l}\text { Conceptualization of the } \\
\text { study; analysis and } \\
\text { interpretation of the data; } \\
\text { and drafting and revising } \\
\text { the manuscript for } \\
\text { intellectual content }\end{array}$ \\
\end{tabular}


Appendix (continued)

\begin{tabular}{|c|c|c|}
\hline Name & Location & Contribution \\
\hline $\begin{array}{l}\text { Maria- } \\
\text { Isabel } \\
\text { Vargas, } \\
\text { MD }\end{array}$ & $\begin{array}{l}\text { Diagnostic Department, } \\
\text { Division of Neuroradiology, } \\
\text { Geneva University Hospital, } \\
\text { Switzerland }\end{array}$ & $\begin{array}{l}\text { Major role in the acquisition } \\
\text { of data and analysis and } \\
\text { interpretation of the data }\end{array}$ \\
\hline $\begin{array}{l}\text { Camille } \\
\text { Thieffry, } \\
\text { MD }\end{array}$ & $\begin{array}{l}\text { Department of APSI, } \\
\text { Intensive Care Unit, Geneva } \\
\text { University Hospital, } \\
\text { Switzerland }\end{array}$ & $\begin{array}{l}\text { Major role in the acquisition } \\
\text { of data and analysis and } \\
\text { interpretation of the data }\end{array}$ \\
\hline $\begin{array}{l}\text { Manuel } \\
\text { Schibler, } \\
\text { MD, PhD }\end{array}$ & $\begin{array}{l}\text { Medicine Department, } \\
\text { Division of Infectiology, } \\
\text { Geneva University Hospital, } \\
\text { Switzerland }\end{array}$ & $\begin{array}{l}\text { Major role in the acquisition } \\
\text { of data and analysis and } \\
\text { interpretation of the data }\end{array}$ \\
\hline $\begin{array}{l}\text { Olivier } \\
\text { Grosgurin, } \\
\text { MD }\end{array}$ & $\begin{array}{l}\text { Medicine Department, } \\
\text { Division of Internal } \\
\text { Medicine, Geneva } \\
\text { University Hospital, } \\
\text { Switzerland }\end{array}$ & $\begin{array}{l}\text { Major role in the acquisition } \\
\text { of data }\end{array}$ \\
\hline $\begin{array}{l}\text { Jérôme } \\
\text { Pugin, MD }\end{array}$ & $\begin{array}{l}\text { Department of APSI, } \\
\text { Intensive Care Unit, Geneva } \\
\text { University Hospital, } \\
\text { Switzerland }\end{array}$ & $\begin{array}{l}\text { Conceptualization of the } \\
\text { study; analysis and } \\
\text { interpretation of the data; } \\
\text { and revising the manuscript } \\
\text { for intellectual content }\end{array}$ \\
\hline
\end{tabular}

Appendix (continued)

\begin{tabular}{lll}
\hline Name & Location & Contribution \\
\hline $\begin{array}{l}\text { Patrice H. } \\
\text { Lalive, MD }\end{array}$ & $\begin{array}{l}\text { Department of Clinical } \\
\text { Neurosciences, Division } \\
\text { of Neurology, Geneva } \\
\text { University Hospital, }\end{array}$ & $\begin{array}{l}\text { Conceptualization of the } \\
\text { study; analysis and } \\
\text { interpretation of the data; } \\
\text { and drafting and revising } \\
\text { the manuscript for }\end{array}$ \\
& $\begin{array}{l}\text { Department, Division } \\
\text { of Laboratory Medicine, } \\
\text { Geneva University }\end{array}$ & \\
& Hospital, Switzerland; & \\
& Department of & \\
& Pathology and & \\
Immunology, Faculty of & \\
& Medicine, University of \\
& Geneva, Switzerland
\end{tabular}

\section{References}

1. Mao L, Jin H, Wang M, et al. Neurologic manifestations of hospitalized patients with coronavirus disease 2019 in Wuhan, China. JAMA Neurol 2020;77:1-9.

2. Helms J, Kremer S, Merdji H, et al. Neurologic features in severe SARS-CoV-2 infection. N Engl J Med 2020;382:2268-2270.

3. Yan R, Zhang Y, Li Y, Xia L, Guo Y, Zhou Q. Structural basis for the recog nition of SARS-CoV-2 by full-length human ACE2. Science 2020;367: 1444-1448.

4. Varga Z, Flammer A, Steiger P, et al. Endothelial cell infection and endotheliitis in COVID-19. Lancet 2020;395:1417-1418.

\section{COVID-19 and Neurologic Disease: Call for Papers!}

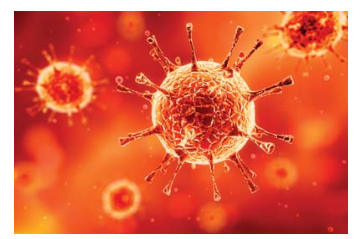

The editors of Neurology are interested in papers that address the neurological aspects of COVID-19 infection and challenges to the management of patients with chronic neurological conditions who have, or are at risk for, the infection. Relevant papers that pass initial internal review will undergo expedited peer review and online publication. We will consider papers posted in preprint servers.

Submit observational studies and clinical trials as Articles and case series and case reports under the Clinical/Scientific Notes category to https://submit.neurology.org/ today!

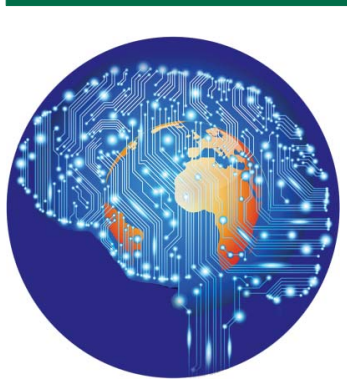

\section{Practice Current: An interactive exchange on controversial topics}

Share your own best practices.

Read commentary with expert opinion.

Explore results on an interactive world map.

NPub.org/NCP/practicecurrent

Neurology ${ }^{\circledR}$ Clinical Practice 


\section{Neurology}

\section{COVID-19-related encephalopathy responsive to high-dose glucocorticoids}

Deborah Pugin, Maria-Isabel Vargas, Camille Thieffry, et al.

Neurology 2020;95;543-546 Published Online before print July 17, 2020

DOI 10.1212/WNL.0000000000010354

This information is current as of July 17, 2020

\section{Updated Information \& Services}

References

Citations

Subspecialty Collections

Permissions \& Licensing

Reprints including high resolution figures, can be found at: http://n.neurology.org/content/95/12/543.full

This article cites 4 articles, 1 of which you can access for free at: http://n.neurology.org/content/95/12/543.full\#ref-list-1

This article has been cited by 1 HighWire-hosted articles: http://n.neurology.org/content/95/12/543.full\#\#otherarticles

This article, along with others on similar topics, appears in the following collection(s):

All Immunology

http://n.neurology.org/cgi/collection/all_immunology

All Neuropsychology/Behavior

http://n.neurology.org/cgi/collection/all_neuropsychology_behavior MRI

http://n.neurology.org/cgi/collection/mri

Vasculitis

http://n.neurology.org/cgi/collection/vasculitis

Information about reproducing this article in parts (figures,tables) or in its entirety can be found online at:

http://www.neurology.org/about/about_the_journal\#permissions

Information about ordering reprints can be found online:

http://n.neurology.org/subscribers/advertise

Neurology ${ }^{\circledR}$ is the official journal of the American Academy of Neurology. Published continuously since 1951, it is now a weekly with 48 issues per year. Copyright () 2020 American Academy of Neurology. All rights reserved. Print ISSN: 0028-3878. Online ISSN: 1526-632X.

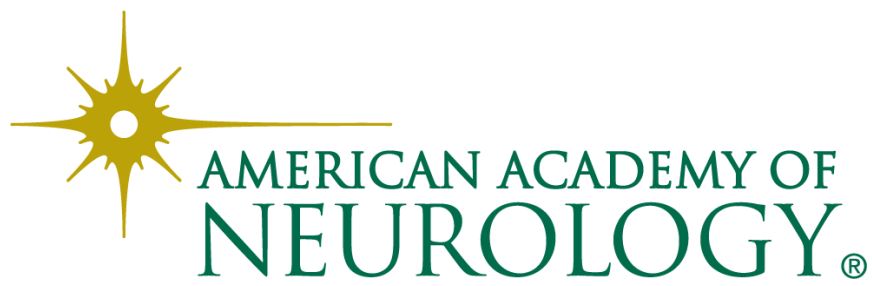

